\title{
Command Responsibility
}

\author{
Mode of Liability for the Crimes of Subordinates or \\ Separate Offence of the Superior?
}

\author{
Chantal Meloni*
}

\begin{abstract}
The nature of command responsibility is still open to debate in international criminal law: is a superior to be held criminally responsible for the crimes committed by his subordinates 'as an accomplice', for having participated in the commission of the crime by omission, or as a perpetrator of a separate offence of dereliction of duty? This article surveys the post-WW2 case law and the first international instruments on this point, and then analyses the jurisprudence of the International Criminal Tribunal for the former Yugoslavia (ICTY). The judges appear to have recently adopted a new approach to Article 7(3) ICTYSt. in that the superior is held responsible 'for failure to prevent or punish with regard to the crimes of the subordinate' and no longer 'for the crimes of his subordinates'. It is a responsibility 'sui generis' indeed, where the crime of the subordinate plays a central role in the attribution of responsibility to the superior. It is, therefore, necessary to carefully consider the relationship between the superior's failure to act and the subordinate's crime, both with regard to objective and subjective elements. The same question finally arises in relation to Article 28 of the Rome Statute, the literal interpretation of which implies that a superior shall be punished for the same crime committed by his subordinates. In order to avoid the risk of holding a person guilty of an offence committed by others in violation of the principle of personal and culpable criminal responsibility, it is crucial to consider separately the different cases of command responsibility, which are based on distinct objective and subjective requirements.
\end{abstract}

\section{The Terms of the Problem}

Command responsibility ${ }^{1}$ has been recognized as a principle of customary international law for a long time. ${ }^{2}$ However, the (legal) nature of command

* Post-doctoral researcher, University of Milan. [chantalmeloni@gmail.com]

1 Although the expression superior responsibility should be preferred since it comprises the military commander and the civilian superior, the traditional military expression command responsibility, which is still largely in use, will also be used in this article without intending any substantial difference of meaning between the two expressions.

2 See K. Ambos, 'Superior Responsibility', in A. Cassese, P. Gaeta, J.R.W.D. Jones (eds), The Rome Statute of International Criminal Law, Vol. I (Oxford: Oxford University Press, 2002) 825-848; 
responsibility is still open to debate in international criminal law: is it a mode of liability for the crimes committed by subordinates or rather a separate offence of the superior for failure to discharge his duties of control pursuant to international law? In other words, is a superior to be held criminally responsible for the crimes committed by his subordinates 'as an accomplice, ${ }^{3}$ or for a separate offence of omission, consisting of the dereliction of his duty to control, prevent or punish? ${ }^{4}$

No doubt, this particular legal question arises within the context of superior responsibility for omission or, more properly, for dereliction of duty. It is clear, in fact, that if the superior contributes with any positive act to the commission of the crime (typically by ordering or instigating the subordinate to commit the crime), he becomes a participant in the crime, and his criminal liability follows from the general principles of accomplice liability. In other words, the question is whether the superior who knew, or had reason to know, that his subordinates were committing or had committed crimes, and failed to take proper measures to prevent the commission of such crimes or to punish them, shall be charged and possibly convicted merely for his omission, or for his subordinates' crime that he failed to prevent or punish.

As it was recently stated by the judges of the International Criminal Tribunal for the former Yugoslavia (ICTY):

a cet égard, se pose la question de savoir si un commandant qui a manqué à son obligation de faire respecter le droit international humanitaire par ses troupes est tenu pénalement responsable de sa propre omission ou plutôt des crimes qui s'ensuivent. ${ }^{5}$

Determining the nature of command responsibility is relevant not only from a theoretical, but also from a practical point of view. On one hand, there is an impact on sentencing in international proceedings. Limiting a superior's responsibility to his failure to prevent or punish may have a substantial impact on sentencing to the extent that the superior would be convicted not for the principal crime (e.g. crimes against humanity, war crimes and genocide), but for a separate offence of omission. This can be observed in the recent conviction of Naser Orić, a former commander of the Srebrenica armed forces,

as regards ICTY case law, see Judgment, Delalić and others (IT-96-21-T), Trial Chamber, 16 November 1998, $\S$ 333, 343 (hereinafter Delalić and others Judgment).

3 'As an accomplice' is used here not necessarily to describe the formal status of the superior pursuant to criminal law categories, but rather from the perspective of the consequences that attach to his liability. In international criminal law (following the Anglo-American system, as well as in many civil law countries) the accomplice is charged and convicted for the (same) crime committed by the perpetrators, i.e. for the principal crime, see E. van Sliedregt, The Criminal Responsibility of Individuals for Violations of International Humanitarian Law (The Hague: TMC Asser Press, 2003), $61 \mathrm{ff}$.

4 For an important contribution on the subject, see O. Triffterer, "Command Responsibility" crimen sui generis or participation as "otherwise provided" in Article 28 of the Rome Statute?, in J. Arnold (ed.), Menschengerechtes Strafrecht, Festschrift für Albin Eser (München: Beck, 2005), 901-924.

5 Judgment, Hadžihasanović (IT-01-47-T), Trial Chamber, 25 March 2006 (hereinafter Hadžihasanović Judgment), § 68 ff. 
who was sentenced by the Trial Chamber of the ICTY to two years of imprisonment (instead of the 18 years requested by the Prosecutor) for failure to prevent the crimes committed by his soldiers. ${ }^{6}$ In the Prosecutor's opinion, the "two years sentence is manifestly inadequate because it is based on a fundamental error in the nature of Orićs criminal responsibility by classifying Orićs crimes as a failure to discharge his duty as a superior, rather than as a mode of liability for the actual crimes, ...?

On the other hand, the effort to accommodate the superior's responsibility for failure to act within the complex net of contributions - typical of the commission of international crimes - is also useful at a national level in terms of the implementation of the Rome Statute in domestic legislation. Difficulties arise if superior responsibility is understood as a mode of liability pursuant to which the superior shall be sentenced for the intentional crimes of his subordinates. This is particularly evident with respect to two aspects of superior responsibility: when the superior negligently failed to know, and thus to prevent or punish, the commission of crimes by his subordinates, and when liability is solely based on the failure to punish. ${ }^{8}$ Some domestic laws have structured at least one aspect of command responsibility - the failure to control or the failure to punish — as a crimen sui generis. ${ }^{9}$

\section{From the Origins of the Principle to the First Codifications}

\section{A. The Post-WW2 Period: Command Responsibility as a Form of Participation}

Going back to the remote origins of the principle, it can be observed that, pursuant to the command responsibility theory, the commander was generally held responsible for the same crime committed by his subordinates. ${ }^{10}$

Surveying several precedents, the judges of the ICTY found that national legislation on war crimes enacted after World War II considered command responsibility as a form of accomplice liability. ${ }^{11}$ The French ordonnance of

6 See infra part 3B.

7 See The Prosecution's Appeal Brief, Orić (IT-03-68-A), 16 October 2006, $\S 10$ (hereinafter The Prosecution's Appeal Brief).

8 See the extensive analysis of M. Damaška, 'The Shadow Side of Command Responsibility', 49 American Journal of Comparative Law (2001) 455-496.

9 See Triffterer, supra note 4, at 903, with reference to the German Völkerstrafgesetzbuch of 2002, which adopted a different solution, defining the failure to control as a separate offence of the superior $(\S 13)$, as well as the failure to report the crime to the competent authorities $(\S 14)$. Cf. infra note 108 .

10 For an interesting historical survey of command responsibility for war crimes, see W.H. Parks, 'Command Responsibility for War Crimes', 62 Military Law Review (1973) 1-104.

11 See Judgment, Halilović (IT-01-48-T), Trial Chamber, 16 November 2005 (hereinafter Halilović Judgment), $\S 3$. 
1944, for instance, declared responsible as an 'accomplice' the superior who 'tolerated' the criminal acts of his subordinates; ${ }^{12}$ a verb which implied that, to be held responsible, the superior actually knew about the crimes and consciously decided not to take action to prevent or repress them.

In this regard, it should be noted that most of the rules referring to the responsibility of superiors adopted during this period can be considered only lato sensu forms of command responsibility, ${ }^{13}$ in that they generally implied a kind of positive participation of the superior in the subordinates' crime: the superior was therefore correctly held responsible for the crime as an accomplice, having contributed directly to the commission of the crime. $^{14}$ During the Nuremberg trials and the subsequent proceedings most of the convictions of high-ranking German commanders and of other subjects holding positions of authority in German industry were actually based on positive acts of the superiors. ${ }^{15}$ Some important convictions, however, were based also on their failure to act. ${ }^{16}$ In these latter cases the judges referred to concepts such as 'acquiescence' according to which to be held criminally responsible for the criminal acts of his subordinates, the superior must be found both to have had knowledge and to have been connected to such criminal acts, either by way of participation or criminal acquiescence. ${ }^{17}$

Similar conclusions can be drawn from the analysis of the case of Japanese General Yamashita, who was sentenced to death because, through his omission, permitted his troops to commit atrocities. ${ }^{18}$ Although no adequate finding was made by the American military commission about the actual knowledge of

12 Art. 4 of the French Ordinance of 28 August 1944, in The UN War Crimes Commission, Law Reports of Trials of War Criminals 1947-48, Vol. IV (Buffalo: Hein, 1997) (hereinafter Law Reports), 87.

13 The responsibility of the superior who ordered or instigated the commission of the crimes by subordinates is often indicated as command responsibility lato sensu, to distinguish it from the responsibility of the superior who failed to prevent or repress the criminal conduct of subordinates (command responsibility stricto sensu).

14 This is, in our view, valid also with regard to Regulation 10 of the Canadian Act respecting war crimes of 1946 (in Law Reports, Vol. IV, 128-129) and Regulation 8(ii) of the British Royal Warrant of 1945 (in Law Reports, Vol. I, 108-199) quoted by the Halilović judgment as examples of command responsibility. A provision about command responsibility stricto sensu was, instead, in the British Manual of Military Law (1958), see Parks, supra note 10, at 17-20.

15 In this regard see, B.V.A. Röling, A. Cassese (ed.), The Tokyo Trial and Beyond: Reflections of a Peacemonger (Cambridge: Polity Press, 1993), 74 ff.

16 Highly significant proceedings on this issue include the Hostage trial and the High Command trial: see infra note 17 .

17 Nuremberg Trial of the United States v. Wilhelm von Leeb (the High Command trial), in Trials of War Criminals before the Nuremberg Military Tribunals under Control Council Law No. 10, Vol. XI (Buffalo: Hein, 1997), 543-512 (hereinafter TWC). See also U.S. v. Wilhelm von List (the Hostage trial), in TWC, Vols X and XI, 1271.

18 The charge against General Yamashita was to have unlawfully disregarded and failed to discharge his duty as a commander to control the operation of the members of his command, permitting them to commit brutal atrocities and other high crimes', in Law Reports, Vol. IV, $3 \mathrm{ff}$. For a survey of the process see R. Lael, The Yamashita Precedent: War Crimes and Command Responsibility (Wilmington: Scholarly Resources, 1982). 
the General with respect to the crimes committed by his soldiers, ${ }^{19}$ it was believed that the crimes were so extensive and widespread, both as to time and area, that they must either have been wilfully permitted by the accused, or secretly ordered by the accused. ${ }^{20}$ In other words, the underlying reasoning of the judges was that Yamashita participated (not physically, but through secret orders or acquiescence) in the commission of the atrocities. ${ }^{21}$

In sum, although post-WW2 case law 'was not uniform in its determination as to the nature of the responsibility arising from the concept of command responsibility, ${ }^{22}$ at that time command responsibility was largely interpreted as a mode of liability by which the superior was responsible for the crimes of the subordinates. This form of responsibility sometimes appeared as a form of participation in the subordinates' crime, and sometimes shifted towards forms of vicarious/imputed liability. ${ }^{23}$ In either case, the superior was charged and convicted for the principal crime (i.e. the underlying offence committed by his subordinates). Command responsibility, however, was not necessarily understood as it is today in terms of being based on a pre-existing legal duty to prevent or punish: in most of the cases the superior was found guilty for having positively contributed to the commission of crimes by his subordinates and therefore sentenced for such crimes. ${ }^{24}$

\section{B. The First 'Codifications': Article 86(2) of Additional Protocol I and Article 7(3) of the ICTY Statute}

The first international instrument to expressly 'codify' this form of responsibility is the Additional Protocol I of 1977 to the Geneva Conventions. In this respect, the wording of Article 86(2) of the Additional Protocol, that the fact

19 The case of General Yamashita has been strongly criticized as an example of a conviction on the basis of strict liability: see M.C. Bassiouni, "Ratione personae and elements of criminal responsibility', in Crimes against Humanity in International Criminal Law (2nd edn., The Hague: Kluwer Law International, 1999). For a different interpretation, see Parks, supra note 10, 22 ff.

20 Quoted in L.C. Green, 'Command Responsibility in International Humanitarian Law', 5 Transnational Law and Contemporary Problems (1995) 319-371, at 336.

21 In this sense, Parks, supra note 10, $22 \mathrm{ff}$, however, concedes that the value of the Yamashita trial lies in the recognition of the existence of an affirmative duty of the superior to take the appropriate measures in his power to control his subordinates, and that the failure to discharge such duty constitutes a violation of the law of war. See also the judgment of the US Supreme Court, in Re Yamashita, 327 U.S. 1 (1945).

22 Halilović Judgment, supra note 11, §48.

23 See Yamashita, supra note 19. See also the Tokyo judgment of the International Military Tribunal for the Far East where the indictment separately charged those who ordered, authorized and permitted' to commit the violations of the laws of war (count 54) and those who deliberately and recklessly disregarded their legal duty to take adequate steps to secure the observance and prevent breaches' of the laws of war (count 55). Nearly the entire Japanese cabinet was found responsible for war crimes against prisoners under the latter count. As stated by Judge Röling in his dissenting opinion, 'It seems that the judgment goes too far where it assumes the responsibility of every member of the government for the atrocities committed.... See Cassese, supra note 15.

24 This was however not the case in the Tokyo judgment, supra note 23. 
that a breach of the Conventions or of this Protocol was committed by a subordinate does not absolve his superiors from penal or disciplinary responsibility, as the case may be, if ..., could allow both an interpretation of command responsibility as a mode of liability for the crimes of subordinates, as well as a separate offence of dereliction of duty of the superior. Moreover, not only does this provision remain in principle open to both these readings, but it also does not define the character of the responsibility, whether penal or disciplinary, primary or vicarious, to be imposed on the superior for failure to act. Such a determination is left to the domestic law. ${ }^{25}$

A similar open approach, although limited to a responsibility criminal in character, can be found in the formulation of Article 7(3) of ICTY Statute ${ }^{26}$ and in the related UN Secretary-General's Report stating that 'a commander should be held responsible for failure to prevent a crime or to deter the unlawful behaviour of his subordinates'.

However, the UN Commission of Experts, in its Final Report on the ICTY Statute, ${ }^{27}$ affirmed that superiors are individually responsible for a war crime or a crime against humanity committed by a subordinate', which entails that they considered the superior responsible for the same crime committed by the subordinate. The International Law Commission in its Commentary to the Draft Code of Crimes against the Peace and Security of Mankind of 1996 also stated that a 'military commander may be held criminally responsible for the unlawful conduct of his subordinates if he contributes directly or indirectly to their commission of a crime' and that he 'contributes indirectly to the commission of a crime by his subordinate by failing to prevent or repress the unlawful conduct:. ${ }^{28}$

\section{The Case Law of ICTY}

\section{A. General}

A similar approach was reflected in the early case law of the ad hoc Tribunals, ${ }^{29}$ starting with the landmark judgment in Delalić and others. ${ }^{30}$ That command responsibility is a type of individual criminal responsibility for the illegal acts of subordinates ${ }^{31}$ is a common affirmation in ICTY judgments.

25 See Damaška, supra note 8 , at 486 .

26 'The fact that any of the acts referred to in articles 2 to 5 of the present Statute was committed by a subordinate does not relieve his superior of criminal responsibility if.... An equivalent formulation is contained in Art. 6(3) ICTRSt.

27 Final Report of the Commission of Experts, UN Doc. S/1994/674, 27 May 1994.

28 Draft is available online at http://untreaty.un.org/ilc/texts/instruments/english/draft\% 20articles/7.3.1954.pdf (visited 8 May 2007).

29 For sake of clarity it should be noted that, although in the following analysis, reference has been made specifically to the jurisprudence of the ICTY, the ICTR has also extensively dealt with this subject and has issued important judgments on superior responsibility. See, for instance, the judgments against Kambanda, Musema, Barayagwiza and Kajelijeli.

30 Cf. supra note 2.

31 Delalić and others Judgment, supra note 2, §§ 331-333. 
As was summarized in a recent judgment:

\begin{abstract}
Whether command responsibility is a mode of liability for the crimes of subordinates or responsibility of a commander for dereliction of duty has not been considered at length in the jurisprudence of the Tribunal. However, the consistent jurisprudence of the Tribunal has found that a commander is responsible for the crimes of his subordinates under article $7(3) .^{32}$
\end{abstract}

The exact meaning of the expression 'responsible for the crimes' has not been discussed in the case law until very recently. ${ }^{33}$ In any event, the fact that both in indictments and in sentencing, pursuant to Article 7(3), the superior is usually charged and found guilty (or found not guilty) of the same crime committed by his subordinates, makes it clear that command responsibility has been traditionally considered by the ad hoc Tribunals as a mode of liability pursuant to which the superior is made responsible for the same crime committed by his subordinates. ${ }^{34}$ Nonetheless, as mentioned earlier, some recent judgments of the ICTY seem to challenge this assumption.

\title{
B. From Superior's Responsibility 'for the Crimes of his Subordinates' to Superior's Responsibility for Failure to Act 'With Regard to the Crimes of the Subordinates'
}

Recently a Trial Chamber of the ICTY affirmed that superior responsibility pursuant to Article 7(3) shares 'a common feature' with other modes of liability, and in particular with the instigation and aiding and abetting, in that 'both are accessory to principal crimes committed by other perpetrators. ${ }^{35}$ The difference, however, is that "whereas for a finding of instigation and aiding and abetting there ought to be a certain contribution to the commission of the principal crime, superior criminal responsibility is characterised by the mere omission of preventing or punishing crimes committed by (subordinate) others. $^{36}$

Notwithstanding previous findings whereby superior responsibility was seen as a kind of accessorial liability and 'therefore ... the superior [was] described as responsible "for the acts of his subordinates", the judgment clarifies that 'this does not mean, however, that the superior shares the same responsibility as the subordinate who commits the crime in terms of Article 7(1) of the Statute, but that the superior bears responsibility for his own omission in failing to act', and concludes that the superior is responsible 'merely for his neglect of duty with regard to crimes committed by subordinates. ${ }^{37}$ This expression,

32 Halilović Judgment, supra note 11, 53.

33 Hadžihasanović Judgment, supra note 5, §69.

34 See The Prosecution's Appeal Brief, supra note 7, §§ 159 ff; ibid., § 152.

35 Judgment, Orić (IT-03-68-T), Trial Chamber, 30 June 2006, §§ 292-293 (hereinafter Orić Judgment).

36 Ibid., §293.

37 Ibid. 
if read together with other details of the same judgment, marks a difference in the judges' interpretation of superior responsibility.

The superior is responsible not 'for the crime committed by subordinates' but 'merely' for 'his neglect of duty' with regard to the crimes committed. To this extent, the neglect of duty seems to be considered as a separate crime of omission. This interpretation is confirmed by the fact that in the final paragraphs of the judgment, which refer to the determination of the sentence, the failure to prevent or punish is indicated as the only crime for which the superior is to be sentenced. ${ }^{38}$ Moreover, the Trial Chamber did not find the accused guilty for the crimes of murder and cruel treatment he failed to prevent. On the contrary, as further clarified by the Prosecution in its recent appeal brief, the Trial Chamber erroneously convicted Orić of a separate dereliction of duty crime ("failure to discharge his duty as a superior"), rather than murder and cruel treatment. ${ }^{39}$ In this sense, the criminal liability of the superior under Article 7(3) was limited to the neglect of his duty to act, with regard to the crimes committed by others. This judgment appears to consider superior responsibility not as a mode of liability for the crimes of subordinates, but as an autonomous basis for the superior's responsibility for a separate dereliction of duty offence. ${ }^{40}$

This 'new approach' adopted by the Trial Chamber of the ICTY in the Orić judgment is not a complete anomaly in the case law of the Tribunal; to some extent it can be traced back to the Halilović judgment of $2005,{ }^{41}$ and to the Hadžihasanović judgment, which soon followed. ${ }^{42}$ In the effort to clearly differentiate superior responsibility from the modes of liability provided for in Article 7(1), the Halilović judgment stresses the different nature of Article 7(3), underscoring the fact that it is a responsibility for an omission, pursuant to which the superior is responsible for his failure to act in order to prevent or repress the crimes committed by his subordinates as required by international law:

Thus 'for the acts of his subordinates' as generally referred to in the jurisprudence of the Tribunal does not mean that the commander shares the same responsibility as the subordinates who committed the crimes, but rather that because of the crimes committed by his subordinates, the commander should bear responsibility for his failure to act. ${ }^{43}$

Along the same lines the Hadžihasanović judgment affirms that the accused shall not be convicted for the crimes committed by his subordinates, but only for the failure to fulfil his duty to prevent the crimes or punish the perpetrators. ${ }^{44}$ To this extent, in the judges' view, superior responsibility must be

38 Ibid., $\$ 727$.

39 The Prosecution's Appeal Brief, supra note 7, §152.

40 Ibid., $\$ 158$.

41 Halilović Judgment, supra note 11, §54.

42 Ibid., § 54. See also Hadžihasanović Judgment, supra note 5, §§ 74-75.

43 Halilović Judgment, supra note 11, §54 (emphasis added).

44 Hadžihasanović Judgment, supra note 5, § 2075. 
considered as a mode of personal liability for omission ('un mode de responsabilité personnelle pour omission' $).{ }^{45}$

Similar reasoning had already been expressed in 2003 by some judges of the Appeals Chamber in the context of the decision on interlocutory appeal on command responsibility in the Hadžihasanović case. ${ }^{46}$ In his dissenting opinion Judge Shahabuddeen, although admitting that arguments can be found in support of a reading of Article 7(3) of the Statute as having the effect of making a commander 'guilty for an offence committed by others even though he neither possessed the applicable mens rea nor had any involvement whatsoever in the actus reus', stated that he preferred 'to interpret the provision as making the commander guilty for failing in his supervisory capacity to take the necessary corrective action after he knows or has reason to know that his subordinate was about to commit the act or had done so'. In his opinion, a reasonable reading of the provision cannot make the commander a party to the particular crime committed by his subordinate. ${ }^{47}$ Judge Hunt, in arguing that command responsibility can attach also to situations where the crimes that the superior failed to punish were committed before the assumption of control by the superior over the perpetrators, affirmed that the criminal responsibility of the superior is not a direct responsibility for the acts of the subordinate. It is a responsibility for his own acts (or, rather, omissions) in failing to prevent or to punish the subordinate when he knew or had reason to know that he was about to commit acts amounting to a war crime or had done so. ${ }^{48}$

There is certainly nothing revolutionary in finding the nature of superior responsibility as consisting of the superior's failure to act under a duty to do so. ${ }^{49}$ However, a new element has arisen from recent

45 It may be noted, however, that the uncertainty about the nature of this form of liability results in somewhat contradictory statements on the consequences of a conviction under Art. 7(3) ICTYSt. It is affirmed that the concept of superior responsibility is an exception to the general principles of criminal law, to the extent that it allows a superior to be held responsible for a crime even if he did not take any part in the commission of the crime and even if he did not have the intention to commit the crime, thus contradicting the assumption that the superior should be liable of a separate crime of omission. This judgment represents the first conviction on the sole basis of Art. 7(3) ICTYSt. Hadžihasanović Judgment, supra note 5, §§ 2075-2076.

46 Decision on interlocutory appeal challenging jurisdiction in relation to command responsibility, Hadžihasanović (IT-01-47-AR72), Appeals Chamber, 16 July 2003 (hereinafter Command Responsibility Appeal).

47 Partial dissenting opinion of Judge Shahabuddeen, Command Responsibility Appeal, Hadžihasanović, ibid., §32.

48 Separate and partially dissenting opinion of Judge Hunt, Command Responsibility Appeal, Hadžihasanović, ibid., $§ 13$.

49 The 'failure to act under a duty to do so' has been always recognized by the jurisprudence of the Tribunals as the essence of command responsibility; it is a duty that arises from the superior's possession of effective control over the subordinates; see Judgment, Tadić (IT-94-1-A), Appeals Chamber, 15 July 1999 (hereinafter Tadić Appeal Judgment), §98 ff. It should be recalled that not only those holding de jure positions of authority, but also those exercising de facto powers of control can be charged. For a critical approach, see T. Weigend, 'Bemerkungen zur Vorgesetztenverantwortlichkeit im Völkerstrafrecht', Zeitschrift für die gesamte Strafrechtwissenschaft (2004) 1004-1005. 
ICTY jurisprudence: the fact that in the Orić judgment the superior is (or, at least, appears to be) convicted for a separate crime of 'failure to discharge his duty as a superior', rather than for the crimes of his subordinates. $^{50}$ It will be for the Appeals Chamber ultimately to decide whether such an interpretation is correct and consistent with the international law applied by the Tribunals. In the meantime, some remarks can be made on this issue.

\section{The Relationship Between the Failure to Act of the Superior and the Crimes of Subordinates: A 'Sui Generis' Responsibility for Dereliction of Duty}

In order to establish criminal responsibility pursuant to the principle of command responsibility, the superior's mere failure to act is not sufficient. It has been consistently found that the first (although often implicit) requirement of command responsibility is the actual commission of a crime by a subordinate. $^{51}$ The superior's general failure to control his troops does not entail criminal responsibility per se in international law. ${ }^{52}$ The superior's criminal responsibility flows from the neglect of a specific duty to take the measures that are necessary and reasonable in the given circumstances, in order to prevent those specific crimes or to punish the perpetrators thereof. This implies, on one hand, that the superior who has done everything materially possible to prevent or punish the commission of crimes by his subordinates, should not be held responsible if, notwithstanding his appropriate exercise of control, crimes have been committed; but, on the other hand, it also means that no criminal responsibility can attach pursuant to Article 7(3) of the Statute to the superior who has failed to discharge his duty to control subjects under his command/authority and control as long as no international crime has been committed. ${ }^{53}$

This raises the question of what relationship subsists between the omission of the superior and the crimes of his subordinates in the jurisprudence of the ICTY from two perspectives: first, there is the objective element (causality); second, there is the subjective element (mens rea). In other words: does the omission of the superior need to be causally linked to the subordinates' crime? And secondly: does the mens rea of the superior need to be established with reference to (all) the elements of the crime committed by the subordinates?

50 See The Prosecution's Appeal Brief, supra note $7, \S 152$.

51 At least in the attempted form, see Orić Judgment, supra note 35, §330.

52 The fact that under international law the failure to exercise control properly is not punished does not exclude that it may have disciplinary or even criminal consequences under national law, see Triffterer, supra note 4, at 911.

53 Ibid., $911 \mathrm{ff}$. 


\section{The Objective Relationship between the Superior's Omission and the Subordinates' Crime: The Problem of Causality}

Regarding the objective element, it is not entirely clear whether (and, if so, which kind of $)^{54}$ a causal relationship is required between the omission of the superior and the crimes of the subordinates. ${ }^{55}$

With regard to the failure to prevent, both interpretations of the causal element are theoretically possible. Depending on the one adopted, the principle of command responsibility will assume a different character. In the one case, it will be consistent with the liability of the superior for his mere failure to act (where the crime of subordinates is not linked to the failure of the superior); in the other case, it will be consistent with the liability of the superior for his contribution, and therefore participation, in the crime of subordinates (which would represent the result of the criminal offence).

The jurisprudence of the Tribunal has generally found that there is no need to prove the element of causation in relation to command responsibility. ${ }^{56}$ This accords with the recognition of command responsibility as a form of autonomous liability of the superior, generated by his failure to act and limited to his omission. In this sense, it has been recently affirmed that if it had to be proven that the superior's failure to act causally contributed to the commission of the subordinates' crime, there would be no difference between Article 7(3) and Article 7(1), and superior responsibility would be rendered superfluous. ${ }^{57}$

However, the negation of the element of causation appears to be less consistent with an understanding of command responsibility as a mode of liability pursuant to which the superior is sentenced for the crimes of subordinates. As affirmed in Delalić and others, 'a recognition of a necessary causal nexus may be considered to be inherent in the requirement of crimes committed by subordinates and the superior's failure to take the measures within his power to prevent them. ${ }^{58}$ Therefore, "in this situation the superior may be considered to be causally linked to the offences, in that, but for his failure to fulfil his duty to act, the acts of his subordinates would not have been committed. ${ }^{59}$ Such an interpretation of causality in command responsibility, however, is unsatisfactory to the extent that the judgment flatly concludes there is no requirement of proof of causation as a separate element of superior responsibility under international law. ${ }^{60}$

54 On the problematic causal relationship between the failure to act and the crime committed, see

K. Ambos, Der allgemeine Teil des Völkerstrafrecht, Ansätze einer Dogmatisierung (Berlin: Dunker \& Humblot, 2002), 683 ff.

55 See the important contribution of O. Triffterer, 'Causality, A Separate Element of the Doctrine of Superior Responsibility as Expressed in Article 28 Rome Statute?', 15 Leiden Journal of International Law (2002) 179-205 and, partially critical, Weigend, supra note 49, $999 \mathrm{ff}$.

56 See Judgment, Blaškić (IT-95-14-A), Appeals Chamber, 29 July 2004, § 73 ff.

57 See Orić Judgment, supra note 35, §338.

58 See Delalić and others Judgment, supra note 2, $\$ 389 \mathrm{ff}$.

59 Ibid., §399 (emphasis added).

60 Ibid., $\S 398$. This affirms the existence of a causal nexus to be proven by the Prosecutor, consisting in the superior's power to properly (and thus effectively) control and that without 
With regard to the failure to punish, the situation is different and complicated by the fact that it is highly problematic to require a causal link between a crime committed by a subordinate and the subsequent failure of the superior to punish the perpetrator. ${ }^{61}$ The jurisprudence of the ad hoc Tribunals simply provides that it 'would make no sense to require' a causal link with regard to the failure to punish. ${ }^{62}$ It can be noted that such a finding - consistent with an understanding of command responsibility as an autonomous basis of liability for the superior limited to his failure to act, and more precisely to punish (as a separate offence) - appears to be again unsatisfactory from the opposite point of view (as a mode of liability pursuant to which the superior is made responsible for the crimes of subordinates). ${ }^{63}$

\section{The Subjective Relationship Between the Omission of the Superior and the Subordinate's Crime}

A link between the superior's failure to act and the subordinate's crime can exist also on the subjective level, with reference to the mental element of the superior. The jurisprudence of the ad hoc Tribunals has expressly rejected command responsibility as a form of vicarious or objective liability: it is "undisputed that command responsibility does not impose strict liability on a superior for the offences of subordinates. ${ }^{, 64}$ However, many aspects related to the mens rea of superior responsibility are still open to debate in the case law of the Tribunals. The relevant question to this discussion is particularly whether the mens rea of the superior needs to be established by reference to all the elements of the crime committed by the subordinates. ${ }^{65}$ The main problems arise with respect to the 'has reason to know' standard. ${ }^{66}$ It is discussed whether, to trigger superior responsibility, the information received by the accused (superior) needs to point to a specific crime, or whether it suffices that the superior received information of a general nature that would put him

this failure to control, such crimes - at least most probably - would not have occurred', Triffterer, supra note 4, at 919 and more extensively, supra note 55.

61 The reasoning is of course different if the failure to punish is considered in relation to the commission of future crimes, see Triffterer, supra note 55, at 201-202. From this perspective the superior's failure to punish can be causally related in the sense that it does not deter the commission of future and imminent crimes by the same perpetrators.

62 See Orić Judgment, supra note 35, § 338.

63 For a difficult reconciliation between the failure to punish and the element of causation in command responsibility, see again the position of Triffterer, supra note 55.

64 Judgment, Delalić and others (IT-96-21-A), Appeals Chamber, 20 February 2001 (hereinafter Delalić and others Appeal Judgment), §313 (emphasis added).

65 See Triffterer, supra note 4, 909.

66 Pursuant to Art. 7(3) of the Statute, in fact, the superior can be held responsible not only if he knew, but also if he had reason to know that his subordinates were about to commit crimes or had already committed them. On the interpretation of this controversial standard, see Delalić and others Appeal Judgment, supra note 64, § 233 ff. 
on notice of the risk of crimes being committed. ${ }^{67}$ The Appeals Chamber has found that it is sufficient that a superior 'had some general information in his possession' to prove that he had reason to know, and that 'this information does not need to provide specific information about unlawful acts committed, ${ }^{68}$ As it was clarified in a later judgment, however:

It may not be inferred from this case-law that, where one offence (the 'first offence') has a material element in common with another (the 'second offence') but the second offence contains an additional element not present in the first, it suffices that the superior has alarming information regarding the first offence in order to be held responsible for the second on the basis of Article 7(3) of the Statute (such as for example, in the case of offences of cruel treatment and torture where torture subsumes the lesser offence of cruel treatment). ${ }^{69}$

To be held responsible the superior does not even need to know the identity of the perpetrator (subordinate) of the crime he failed to prevent; it suffices to 'prove[] that the individuals who are responsible for the commission of the crimes were within a unit or a group under the control of the superior. ${ }^{70}$ The fact that, as emerges from the case law of the Tribunal, the mens rea of the superior does not need to be established with reference to (all) the objective and subjective elements of the subordinates' crime appears more consistent with a responsibility for failure to act rather than with a form of participation in the crime of subordinates. ${ }^{71}$

\section{A 'Sui Generis’ Responsibility}

What actually emerges by the case law of the ad hoc Tribunals is that the superior's responsibility is a 'sui generis' responsibility — as it has been in fact repeatedly labelled ${ }^{72}$ — which departures from the known categories of criminal liability recognized by most legal systems.

Although apparently clear in its literal meaning ${ }^{73}$ and in its elements ${ }^{74}$ the ambiguity of such responsibility is intrinsic in the particular link existing

67 See Judgment, Krnojelac (IT-97-25-A), Appeals Chamber, 17 September 2003, § 149 ff (hereinafter Krnojelac Appeal Judgment).

68 Delalić and others Appeal Judgment, supra note 64, § 238.

69 Krnojelac Appeal Judgment, supra note 67, § 155.

70 Orić Judgment, supra note $35, \S 315$.

71 See again Triffterer, supra note 4, 909.

72 Cf. Halilović Judgment, supra note 11, § 78; Hadžihasanović Judgment, supra note 5, § 75; Orić Judgment, supra note 35, § 293.

73 'The literal meaning of Article 7(3) is not difficult to ascertain. A commander may be held criminally liable in respect to the acts of his subordinates in violation of Articles 2 to 5 of the Statute.... The commander would be tried for failure to act in respect of the offences of his subordinates in the perpetration of which he did not directly participate: Delalić and others Appeal Judgment, supra note $64, \S 225$ (emphasis added).

74 As consistently found from the Delalic and others judgment, three elements need to be proven for superior responsibility to be found: (i) the superior-subordinate relationship; (ii) the mental element of the superior and (iii) the failure to take the necessary measures to prevent 
between the superior's criminal liability for dereliction of his duty to act and the crime (not prevented or punished) committed by his subordinate.

This form of liability is actually unknown in domestic criminal law and represents a hybrid of several concepts. On one hand, it is not consistent with any form of complicity, since there is no need to prove the causal link with the underlying crime committed by the subordinate and since the mens rea threshold is lower than the one required for complicity. ${ }^{75}$ On the other hand, it is hardly conceivable as a separate offence of failure to act since the liability of the superior is strictly and necessarily dependent from the commission of the crime by the subordinate. This is well reflected with respect to the sentencing process: notwithstanding the affirmation that the failure to prevent or punish 'in itself is the only crime for which he/she is to be sentenced', it is affirmed that the determination of sentence shall be considered in proportion to the gravity of the crimes committed by the subordinates. ${ }^{76}$ The gravity of the offence of the superior, which is indicated as the most important criterion to determine the measure of the sentence to be imposed ${ }^{77}$ actually depends on various factors among which the gravity of the subordinates' crime is the first of the principal factors. ${ }^{78}$ Therefore, even assuming that under Article 7(3) an individual is not convicted for the crimes committed by his subordinates, ${ }^{79}$ the fact that the gravity of the subordinates' crime is one of the most important sentencing factors shows the crucial role played by the crime of subordinates in assessing the (gravity of the) responsibility of the superior.

In conclusion, superior responsibility, as interpreted by the jurisprudence of the ad hoc Tribunals, is a sui generis mode of liability for failure to act that finds no direct equivalent in domestic criminal law. This conclusion does not mean, however, that command responsibility can avoid respecting the fundamental principles of criminal law, especially the principle of individual and culpable criminal liability. ${ }^{80}$ Depending on the subjective and objective elements

or punish. A fourth element can be added: the commission of the crime by persons other than the superior, see Orić Judgment, supra note 35, § 294 and related notes.

75 In order to assess accomplice liability for an intentional offence, the minimum criteria required are the accomplice's awareness of making a contribution that facilitated the commission of the crime and the substantial and direct effect of the contribution on the commission of the crime. See Judgment, Furundžija (IT-95-17/1-T), Trial Chamber, 10 December 1998, $§ § 22$ ff.; see also Art. 2 of the Draft Code of Crimes against the Peace and Security of Mankind of 1996 and its Commentary by the International Law Commission, supra note 28. For a broader analysis, see E. Amati, 'Concorso di persone nel diritto penale internazionale', in Digesto Discipline Penalistiche, Appendice di approfondimento (Torino, 2004), $128 \mathrm{ff}$.

76 Orić Judgment, supra note $35, \S 727$ (emphasis added).

77 Ibid., $\$ 726$ with related notes.

78 Ibid., $\$ \$ 728-729$. The Trial Chamber found that in determining the gravity of the subordinates' crimes in relation to the responsibility of the superior the following factors shall be considered: the legal nature of the offences, their scale and brutality, their impact upon the victims and their families and the extent of the long term physical, psychological and emotional suffering of the survivors.

79 Ibid., $\$ 724$.

80 See Damaška, supra note 8. 
actually present in a particular case, both readings (as a responsibility for mere failure to act or as a responsibility for the subordinates' crimes) become theoretically possible. ${ }^{81}$

\section{Article 28 of the Rome Statute: Conclusions in the Light of the Principle of Culpability}

Superior responsibility can never be intended as a normal form of complicity. This follows from the necessary superior-subordinate relationship and from the particular requirements linked to the status of superior. ${ }^{82}$ For the same reasons, however, considering the peculiar nexus between the superior's failure to act and the crime of the subordinate, superior responsibility can neither be intended as introducing a new and separate crime of the superior in international law, besides war crimes, crimes against humanity, genocide and aggression (once it is defined). It is a mode of criminal liability for international offences that presents different aspects depending on the facts in each case. The question raised in the title is merely a problem of attribution of criminal acts, both in an objective (causation) and in a subjective (culpability) sense: no one, in fact, can be punished for a wrongful act unless the act is attributable to him..$^{83}$

The judges of the International Criminal Court (ICC) will face similar problems. According to the wording of Article 28 of the Rome Statute, a superior 'shall be criminally responsible for crimes within the jurisdiction of the Court' committed by his subordinates 'as a result' of his 'failure to exercise control properly'. From a literal interpretation of this provision it follows that the superior is responsible (and, therefore, should be punished) for the principal crime committed by his subordinates. ${ }^{84}$ However, it is necessary to avoid the risk of holding someone guilty for an offence committed by others in violation of the principle of individual and culpable criminal responsibility. ${ }^{85}$

81 Doctrinally, as it has been correctly affirmed, the concept of command responsibility falls between liability for omission and complicity, G. Werle, Völkerstrafrecht (Tübingen: Mohr Siebeck, 2003), 179.

82 The Garentenstellung imposed on the superior by international law reveals the rationale beyond such responsibility, aimed at strengthening the preventive and deterrent effect of international law provisions; see, in this sense, the affirmative duties established by Art. 87 additional protocol I of 1977 and its commentary by J. De Preux, 'Article 87', in C. Pilloud et al. (eds), Commentary on the Additional Protocols of 8 June 1977 to the Geneva Conventions of 12 August 1949 (Geneva: ICRC, 1987), 1017-1023.

83 G.P. Fletcher, Rethinking Criminal Law (Oxford: Oxford University Press, 2000), 454.

84 See Weigend, supra note 49, 1003-1004, referring to superior responsibility under Art. 28 as 'eine erweiterte Form der Haftung für fremdes Unrecht'.

85 A. Cassese, International Criminal Law (Oxford: Oxford University Press, 2003), 136 ff. For the adoption of this principle by the Rome Statute, see N. Pisani, 'L'elemento psicologico del crimine internazionale nella parte generale della Corte penale internazionale', Rivista Italiana di Diritto e Procedura Penale (2001) $1370 \mathrm{ff}$. 
It is possible to distinguish various cases of superior responsibility ${ }^{86}$ on the basis of their different objective and subjective requirements as provided for in Article $28 .{ }^{87}$ Under the Rome Statute the superior is responsible for having failed to take all necessary and reasonable measures within his power to prevent or punish ${ }^{88}$ the criminal acts of the subordinates if he knew, should have known (with regard to military commanders), or consciously disregarded information which clearly indicated that the subordinates were committing or were about to commit such crimes (with regard to civilian superiors). Article 28, thus, introduces an exception to the general rule on mens rea adopted by the Statute. ${ }^{89}$ Unlike the superior who knew, ${ }^{90}$ the commander who should have known does not possess the actual knowledge about the risk, and therefore cannot intentionally fail to prevent or punish the commission of crimes by his subordinates. ${ }^{91}$ In this case, the omission can be negligent, to the extent that the superior was negligent in failing, under a duty to do so, to consider the information that should have alerted him to the (risk of) commission of criminal acts by the subordinates. $^{92}$ Similarly, the omission of the superior who consciously disregarded the information, ${ }^{93}$ is interpreted as introducing a form of gross

86 See G. Carlizzi, 'L' hypothèse spéciale de responsabilité du supérieur hiérarchique dans le Statut du Tribunal Pénal Internationale pour l'ex-Yougoslavie', in E. Fronza and S. Manacorda (eds), La justice pénale internationale dans les décision des tribunaux ad hoc (Milano: Giuffrè, 2003), 150.

87 It is 'logically appropriate and relevant for practical purposes of sentencing to draw a distinction between different classes' of command responsibility: see Cassese, supra note 85, at 206.

88 Where 'punish' in Art. 28 is intended to encompass the two expressions 'repress' and 'submit the matter to the competent authorities'.

89 Art. 28, holding responsible the superior that 'should have known' of the crimes, is a departure to the general mens rea rule provided for by Art. 30 ICCSt., pursuant to which to be criminally 'responsible and liable for punishment for a crime within the jurisdiction of the Court', it is required that 'the material elements are committed with intent and knowledge': see A. Eser, 'Mental Elements - Mistake of Fact and Mistake of Law', in Cassese, Gaeta, and Jones (eds), supra note 2, $889 \mathrm{ff}$.

90 Such knowledge can be proven directly or through circumstantial evidence, but can never be presumed, cf. Delalić and others Judgment, supra note 2, §§ 384-386; Judgment, Aleksovski (IT-95-14/1-T), Trial Chamber, 25 June 1999, § 80.

91 As a general rule of criminal law, intent does not require only the willingness to commit or to omit something, but also knowledge (i.e. awareness) of the factual circumstances underlying the situation. On the two-fold notion of knowledge, and particularly on its role as a part of intent, see Cassese, supra note 85, at 162 ff. See also, Fletcher, supra note 83, at 449.

92 This standard, although still debated, would introduce a form of negligent ignorance based on the violation of the duty to control subordinates imposed on the superior by international law: see K. Ambos, supra note 2, $864 \mathrm{ff}$. Arguments along these lines are found, inter alia, in the US Model Penal Code, Art. 2.02(2)(d). For a brief survey on this matter, see M. Neuner, 'Superior responsibility and the ICC Statute', in G. Carlizzi, G. Della Morte, S. Laurenti and A. Marchesi (eds), La Corte Penale Internazionale (Napoli: Vivarium, 2003) 267-278.

93 This form of culpability, is similar to the standard the jurisprudence of the ICTY has referred to as wilful blindness, that is, when a superior "ignores information within his actual possession compelling the conclusion that criminal offences are being committed, or are about to be committed'. Cf. Delalić and others Judgment, supra note $2, \S 387$. 
negligence (also called conscious negligence in civil law), or a form of recklessness. ${ }^{94}$

With regard to the failure to prevent, a superior may be held accountable for the crime of his subordinates pursuant to the basic criminal law principles on accomplice liability by omission ${ }^{95}$ and on commission by omission ${ }^{96}$ to the extent that both the subjective and objective requirements are fulfilled, that is, when he intentionally fails to take the measures in order to prevent the crime knowing that his subordinates are committing it and being aware that the crime will occur in the ordinary course of events. ${ }^{97}$ In this case, the superior may also be considered as an accomplice in the crimes of his subordinates in that, with his intentional failure to act under a duty to do so, he substantially contributes to the commission of the crimes by the subjects under his control. $^{98}$ In the case of the superior who negligently fails to prevent a crime, it is also theoretically possible to hold him responsible for the crimes committed by his subordinates 'as a consequence' of his negligent failure to prevent them, but this is more problematic. It is debated in criminal law whether is possible to negligently participate in an intentional offence; notwithstanding some arguments in favour, most of the authors tend to exclude this possibility. ${ }^{99}$ However, some domestic systems recognize the possibility of holding someone criminally

94 For the concept of recklessness, unknown in civil law (it falls between conscious negligence and dolus eventualis), see Fletcher, supra note 83. See also the US Model Penal Code, Art. 2.02(2)(c). To consciously disregard, on one hand, implies that simple ignorance is not enough but, on the other hand, does not require that the superior desired or intended the crimes be committed; see Neuner, supra note 92, at 274-276.

95 On participation by omission in international criminal law, see the study of K. Welz, Die Unterlassungshaftung im Völkerstrafrecht (Freiburg, 2004), in particular, 241ff.

96 Pursuant to this principle, someone can be held criminally responsible for a result if, under a legal duty to do so, he fails to act in order to prevent the result, and a causal link exists between his failure to act and the result. Therefore, assuming that international law imposes on the superior a Garantenstellung consisting of the duty to control and to prevent the crimes of subordinates, such crimes can be attributed to the superior if he intentionally fails to fulfil his duty and they occur as a consequence of his failure. The principle of 'commission by omission' is not recognized by every national system: it is not recognized in France, but is recognized in Italy and Germany. For the USA system, but with a broader view, see Fletcher, supra note 83, at $581 \mathrm{ff}$

97 See on Art. 30(2) ICCSt., Eser, supra note 89.

98 See A.M. Maugeri, 'La responsabilité des commandants dans le Statut de la Cour pénale internationale et la défense d'ordres supérieurs', in M. Chiavario (ed.), La justice pénale internationale entre passé et avenir (Milan: Giuffre, 2003), $263 \mathrm{ff}$.

99 The early jurisprudence of the ICTY recognized 'a requirement of intent, which involves awareness of the act of participation coupled with a conscious decision to participate by planning, instigating, ordering, committing, or otherwise aiding and abetting the commission of a crime', Judgment, Tadić (IT-94-1-T), Trial Chamber, 7 May 1997, §674. The later jurisprudence generally adopted a lowered threshold of participation, emphasizing the cognitive element ('knowledge that the act will assist') over the volitional element. See Ambos, supra note 54, at 263-326; 362-370; 638 ff. Under the Rome Statute, the mens rea threshold of complicity has been significantly raised: Art. 25(3)(c) now explicitly requires that the accomplice acts 'for the purpose of facilitating' the commission of the crime. Cf. A. Di Martino, 'La disciplina del concorso di persone', in A. Cassese, M. Chiavario, G. De Francesco (eds), Problemi attuali della giustizia penale internazionale (Torino: Giappichelli, 2005), $189 \mathrm{ff}$. 
responsible for an intentional offence committed by others on the sole basis of his negligent behaviour. ${ }^{100}$ As an argument in favour, it may also be contended that the omission of the superior is causally linked with the crime, in that 'by breaching his supervisory duty' the superior 'has in some way contributed to bringing about the offence. ${ }^{101}$ Nevertheless it should be noted that, pursuant to the principles of culpability and proportion of sanctions, it would be necessary to introduce a gradation in the degree of criminal liability of the superior at least at the sentencing stage, ${ }^{102}$ as the superior did not intend to 'contribute' in the crime. ${ }^{103}$

Finally, with regard to the failure to punish, where no real causal link subsists between the subsequent failure to act of the superior and the crime previously committed, the conviction of the superior for the same crime committed by the subordinates is difficult to justify. ${ }^{104}$ An interesting view has been proposed on this matter, which maintains that Article 28 would contain a double causal connection: the first (and real) one occurring between the superior's first omission, the failure to control the subordinates, and their crimes; the second one occurring between the failure to take the measures to prevent or punish and the crimes. Taking the appropriate measures, the superior would have a 'second chance' to stop the moving chain of causality he started by his failure to control. If he fails to do so a 'strengthening effect' occurs, representing the second causal connection between the superior's omission and the subordinates' crime. ${ }^{105}$

In conclusion, it can be observed that, as far as the failure to prevent is concerned, depending on whether or not the superior actually knew about the subordinates' crime, superior responsibility would be more consistent with a form of complicity in the former case, and more consistent with a responsibility for mere violation of the specific duty to act in the latter case. ${ }^{106}$

100 Art. 57 of the Italian Criminal Code, for instance, provides for a form of criminal liability of the director of a newspaper who negligently fails to exercise his duty to supervise for the wilful crimes committed by others though the newspaper. See F. Albeggiani, I reati di agevolazione colposa (Milan: Giuffre, 1984).

101 Cassese, supra note 85, at 207.

102 Similarly, Maugeri, supra note 98, at $268 \mathrm{ff}$.

103 The case at hand could also be considered as a form of accomplice liability, designed under the 'natural and probable consequence' doctrine, where the superior bears responsibility for all the foreseeable consequences of his conduct. This implies, however, that the superior has intent, or at least knowledge, with regard to his conduct, see T. Wu and Y.S. Kang, 'Criminal Liability for the Actions of Subordinates - the Doctrine of Command Responsibility and its Analogues in United States Law', 38 Harvard International Law Journal (1997) 272-297.

104 Liability for failure to punish could be theoretically based on the common law doctrine of the 'accessory after the fact', which is however obsolete and has been rejected as such: see the Defence's Motion to strike portions of indictment alleging 'failure to punish' liability, Čerkez (IT-95-14/2-PT), 11 December 1997. In any case, Art. 25 ICCSt. does not admit forms of complicity after the fact. See van Sliedregt, supra note 3, at $111 \mathrm{ff}$.

105 See Triffterer, supra note 55, at 179 ff. For a partially critical view, see Weigend, supra note 49 , at $999 \mathrm{ff}$.

106 T. Weigend, 'Zur Frage eines internationalen allgemeinen Teils', in B. Schünemann (ed.), Festschrift für Claus Roxin (Berlin, New York: Verlag de Gruyter, 2001), 1397. 
Indeed, when a superior intentionally fails to prevent the commission of crimes by his subordinates, the nature of command responsibility may become very close to a form of complicity ${ }^{107}$ and the superior may be convicted for the consequences of his failure to act, namely, for the subordinates' crime. More difficulties arise in holding the superior responsible for the principal crime committed by his subordinates that he negligently failed to prevent. Although theoretically possible, the full respect for the principle of culpability recommends a cautious approach to convicting a superior for the crimes of his subordinates that he negligently failed to prevent, in order to avoid the risk of convictions based on strict liability. This would be the case if the following two conditions were not properly proven: (i) that the superior actually had the material possibility to exercise his control properly; (ii) that, if the superior had properly exercised his control, he would have known of the risk.

With regard to the cases of failure to punish, where the wrongfulness of the superior's omission is concentrated in the violation of the specific legal duty to act typical of the subject endowed with powers of command and control, the conduct of the superior cannot fulfil any participation in the (antecedent) crime of the subordinate. The nature of superior responsibility in these cases should thus be more conveniently found in the mere failure to act under a duty to do so. Consequently, the superior should not bear responsibility for the subordinates' crimes 'as if he had committed them' on the sole basis of his failure to punish them.

As emerges from this brief analysis, great care must be taken that the different features of the forms of superior responsibility are taken into account — particularly at a national level when implementing the principle of superior responsibility into domestic law — in order to avoid potential violations of the fundamental principle of individual and culpable criminal liability. ${ }^{108}$

107 Command responsibility should always be distinguished from the other forms of complicity provided for in Art. 25(3) ICCSt. Pursuant to Art. 28, superior responsibility is 'in addition to other grounds of criminal responsibility' under the Rome Statute. 'In the case where both the provisions, Articles 25 and 28, are applicable the active participation should always prevail: Triffterer, supra note 55, at 188.

108 The German Völkerstrafgesetzbuch (VStGB) of 2002, for instance, adopted a good solution on this point, in that it implemented the principle of superior responsibility in three different provisions having different requirements and consequences, see Weigend, supra note 49 , at 1026-1027. On the VStGB, see G. Werle and F. Jessberger, 'Das Völkerstrafgesetzbuch', Juristen Zeitung (2002), 729 ff. The majority of domestic legislations, (including Italy) are still missing a regulation on this point. 